\title{
Patterns and drivers of lichen species composition in a NW-European lowland deciduous woodland complex
}

\author{
Pat Wolseley $^{1} \cdot$ Neil Sanderson $^{2} \cdot$ Holger Thüs $^{1} \cdot$ \\ Daniel Carpenter ${ }^{3} \cdot$ Paul Eggleton $^{1}$
}

Received: 4 November 2015/Revised: 2 November 2016/Accepted: 10 November 2016/

Published online: 24 November 2016

(C) The Author(s) 2016. This article is published with open access at Springerlink.com

\begin{abstract}
We surveyed lichens in an extensive area of lowland deciduous oak and beech dominated forest under wood pasture management within the New Forest National Park, southern England. This provided the basis for an investigation of factors affecting the species density and composition of epiphytic lichen communities. Fifteen 1 hectare plots were established in the same sites as a parallel invertebrate survey, of which nine were in old growth forest and six in oak plantations of between c. 150 and 300 years old. In each plot 12 trees were identified for sampling and lichens were sampled on four aspects of each trunk. Results at the plot level showed that species density was significantly higher in the old growth woodland plots from those in plantations. Plot age had a significant effect on species on oak but this was not significant for lichen communities on beech. The species density of lichens associated with Trentepohliaceae photobionts on oaks showed a linear positive relationship with increasing plot age while the species density of species with other coccal green Chlorophyta decreased with age of the plot. A major part of the lichenised fungi with Trentepohliaceae photobionts includes indicator and notable species used in conservation evaluation and this component is most affected by fragmentation and isolation of forest sites. The results emphasise the importance of long term connectivity and ecological continuity in this extensive mosaic of lowland deciduous forest.
\end{abstract}

Communicated by Pradeep Kumar Divakar.

This article belongs to the Topical Collection: Forest and plantation biodiversity.

Electronic supplementary material The online version of this article (doi:10.1007/s10531-016-1250-3) contains supplementary material, which is available to authorized users.

Pat Wolseley

p.wolseley@nhm.ac.uk

1 Department of Life Sciences, The Natural History Museum, Cromwell Rd, London SW75BD, UK

23 Green Close, Woodlands, Southampton, Hampshire SO40 7HU, UK

3 Thames Valley Environmental Records Centre, Oxfordshire County Council, Old Station Way, Eynsham OX29 4TL, UK 
Keywords Epiphytic lichens · Fragmentation · Old growth forest · Photobiont · Plantation · Wood pasture

\section{Introduction}

Lichens have long been used as indicators of environmental change due to their comparatively slow growth rates, their occurrence across a wide range of conditions and the association of different species with specific microhabitats that develop over time (Ellis and Coppins 2010; Giordani et al. 2012; Hawksworth 1974). As a symbiosis of a fungus and a photobiont, or multiple photobionts, with the photobionts providing the nutrition for the system, they are highly dependent on the ecological limitations of their photosynthetic partner (Hedenås et al. 2007; Marini et al. 2011). In the field three major groups of lichen photobionts can be readily identified: two groups of Chlorophyta algae and cyanobacteria. Most lichenised taxa within the Chlorophyta are impossible to identify in the field, except for the family Trentepohliaceae. In this family lichenised cells usually retain a characteristic yellow-orange colour which is often visible in the lichen thallus after removing overlying fungal tissues. Lichens with this group of algae as a photobiont are collectively described as trentepohlioid. Trentepohlioid algae are predominantely associated with lichens in a stable environment of temperature and moisture e.g. associated with wet tropical conditions and with sheltered woodlands in temperate conditions (Marini et al. 2011). The presence of veteran trees in forests of unbroken ecological continuity is associated with a specialist group of lichens that are used as indicators of old growth forests. This group includes a high percentage of trentepohlioid and cyanobacteria-associated lichens (Rose 1976; Coppins and Coppins 2002). Other photobionts which lack an orange-yellow pigmentation are here summarised as coccoid green Chlorophyta. Many lichens with coccoid green Chlorophyta tolerate high light intensity and pronounced alternate drying and wetting cycles (Candotto et al. 2015), resulting in the prevalence of these lichens in well-lit sites such as in the canopy or in open-grown wood pasture.

The evidence for woodland continuity in European woodlands rarely exceeds a few hundred years. Contemporary research deals mainly with plantations and with sites where human management has allowed ancient trees to survive (Ranius et al. 2008). Yet prior to the arrival of humans most of Europe was covered in woodland (Kaplan et al. 2009) which also supported a great variety and number of grazing animals that are thought to have created open wood pastures with lawns and open spaces (Rose 1992; Vera 2000). Wood pasture supports a range of tree species, ages and tree densities, including open-grown trees with low branches, veteran and decaying trees as well as standing and fallen dead wood (Harding and Rose 1986; Leppik et al. 2011; Rose 1992), all of which provide a diversity of specialist niches for epiphytic lichens.

The New Forest contains the most extensive area of wood pasture in Western Europe in a landscape mosaic of forest interspersed with areas of heathland both of which have been preserved since the creation of the forest as a royal hunting preserve since 1066. Today the wood pasture is maintained as common land for grazing by ponies, cattle, sheep and pigs (Tubbs 2001). This continuity is associated with a great diversity of biota (Newton 2010) and the New Forest was declared a National Park in 2005 and a special area for conservation (SAC) by the European Commission (2012). Within the National Park there are also plantations of native oaks that were created as enclosures from c. 300 years ago and this 
practice continued up to c. 150 years ago. This landscape has provided us with an opportunity to investigate the distribution of lichen communities across the New Forest in both old growth and plantation woodlands, as well as the effects of isolation and fragmentation where changes in management practices have occurred within and around the forest. The establishment of 15 one ha plots in both old growth wood pasture and in enclosed plantation woodlands of the New Forest for quantitative soil macrofauna sampling (Carpenter et al. 2012) provided a basic structure within which to undertake a quantitative survey of epiphytic lichens, to explore patterns of epiphytic lichen species density and composition, as well as their associated photobionts in relation to substrate, tree species and plot age and to correlate these with the effects of fragmentation and isolation of woodland sites in an area of lowland Britain where human population density has remained comparatively low.

\section{Methods}

\section{Site selection and study design}

The New Forest National Park covers approximately 56,000 hectares of wood, heath and settlements between the cities of Bournemouth and Southampton. Although it is an area of low air pollution today, it formerly was affected by the oil-fired power plant at Fawley (Rose and James 1974; Morgan-Huws and Haynes 1973) that was decommissioned in 2013. As recently as 2005, high levels of $\mathrm{SO}_{2}$ were emitted exceeding $266 \mathrm{mgm} / \mathrm{m}^{3}$ more than 60 times in that year (DEFRA 2015). Rose and James (1974) reported effects from high levels of $\mathrm{SO}_{2}$ while the power plant was operating, particularly on the abundance of Lecanora conizaeoides on exposed trees around Tantany wood, which is only $7 \mathrm{~km}$ west of the power station. The New Forest has been known for its rich lichen communities since the 19th century when Crombie recorded that highly pollution sensitive cyanobacterial lichens in the Lobariaceae and Pannariaceae were frequent (Crombie 1894). These now include the most threatened or extinct species in the New Forest (Sanderson 2010). The National Park includes large areas of old growth forest as well as oak plantations ranging from c. 150 to $>300$ years old (Carpenter et al. 2012), now maintained as wood pasture. In our study the major tree species included oak-Quercus petraea, Quercus robur (and hybrids of those two species), beech (Fagus sylvatica) and holly (Ilex aquifolium) together with a range of other native and introduced species at low densities. The pattern of lichen species density on different age classes of oak is complicated by the presence of $Q$. robur and $Q$. petraea (as well as hybrids in the plots). Both species occur widely and hybrids are common due to the early plantations being seeded from local acorns. As a result in this paper $Q$. petraea, $Q$. robur and hybrids are treated as a single taxon in the analysis.

Sites for survey were allocated using mapped vegetation units supplied by the Forestry Commission, which distinguished historic old growth woodlands from plantations. Fifteen woodland plots, already defined for a soil macrofauna survey (Carpenter et al. 2012) representing deciduous woodland in old growth and plantation habitats and located within core and peripheral areas of the Park (Fig. 1; Table 1) were selected.

Based on historic records, summarised in Sanderson (2007), eleven of the plots occur within two main blocks of woodland and four represent wooded areas which have been outliers to these main blocks since medieval times. The northern block includes plots BSW and SWW, the southern block includes plots BWW, MAW, WWW and TTW as well as the 


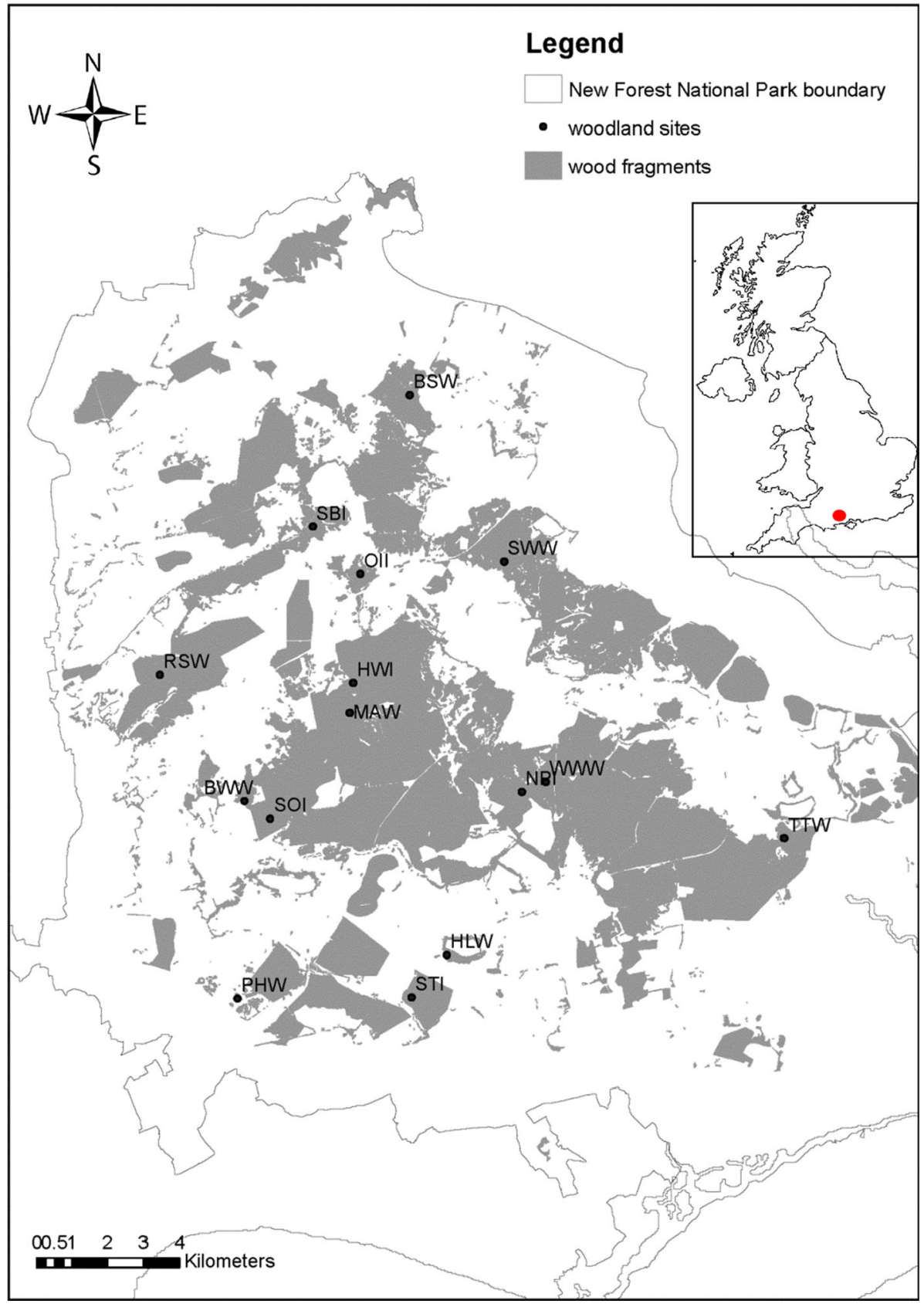

Fig. 1 Simplified map of New Forest National Park (boundary-solid line) showing location of the New Forest in the UK and the position of plots (codes used in Tables 1,2) in woodland areas of the National Park (shaded areas) 
Table 1 Woodland sites and locations in the New Forest National Park: names and codes used in the paper; management, $O G W$ old growth woodland; plot age and location

\begin{tabular}{llllll}
\hline Site name & Label & Habitat type & Age (years) & Latitude & Longitude \\
\hline Bramshaw Wood & BSW & OGW & 500 & N50.83147 & W001.67532 \\
Berry Wood & BWW & OGW & 500 & N50.84550 & W001.69617 \\
Hincheslea Wood & HLW & OGW & 500 & N50.80612 & W001.61535 \\
Highland Water Inclosure* & HWI & Plantation & 242 & N50.87523 & W001.65234 \\
Mark Ash Wood & MAW & OGW & 500 & N50.86767 & W001.65377 \\
New Park Plantation & NPI & Plantation & 203 & N50.84746 & W001.58524 \\
Ocknell Inclosure & OII & Plantation & 243 & N50.90335 & W001.65153 \\
Plain Heath Woodland & PHW & OGW & 500 & N50.79558 & W001.70199 \\
Red Shoot Wood & RSW & OGW & 500 & N50.87748 & W001.72989 \\
South Bentley Inclosure & SBI & Plantation & 311 & N50.91502 & W001.66836 \\
South Oakley Inclosure & SOI & Plantation & 158 & N50.84100 & W001.68586 \\
Set Thorns Inclosure & STI & Plantation & 200 & N50.79538 & W001.62963 \\
Shaves Wood & SWW & OGW & 500 & N50.90586 & W001.59178 \\
Tantany Wood & TTW & OGW & 500 & N50.83527 & W001.48021 \\
Whitley Wood & WWW & OGW & 500 & N50.84989 & W001.57546 \\
\hline
\end{tabular}

* Highland Water Inclosure is a late enclosure site that was never clear-felled

enclosure (plantation) sites OII, HWI, SOI, SBI and NPI. Outlying patches of old growth woodland sites are represented by plots RSW, PHW and HLW and enclosure site STI.

One hectare plots were identified from a central point marked for the invertebrate survey, and the plot area based on a radius of $56.41 \mathrm{~m}$ from the centre, as in the Bioassess project (Scheidegger et al. 2002). Within the hectare plot, sampling points were identified at twelve predetermined distances along compass directions from the central point, and the nearest tree to the sampling point selected in alternate size classes $(<$ and $>36 \mathrm{~cm}$ diameter). In order to accommodate bark $\mathrm{pH}$ as a factor, trees were selected from alternate bark $\mathrm{pH}$ groups where this was possible (Scheidegger et al. 2002). Those with relatively acidic bark including all Quercus, Betula, Pinus and Castanea species were distinguished from trees with higher bark $\mathrm{pH}$ including Fagus, Acer and Ilex. Tree species were recorded, and girth of each tree at $1.5 \mathrm{~m}$ above ground level was measured. Lichens were sampled on $\mathrm{S}, \mathrm{N}, \mathrm{E}$ and $\mathrm{W}$ aspects of each tree trunk using a ladder quadrat with five consecutive $10 \mathrm{~cm}$ square quadrats, placed at $1.5 \mathrm{~m}$ at the upper edge. Species in each $10 \mathrm{~cm}$ square were recorded providing a frequency scale of one to 20 for each species on the trunk. Within each quadrat all lichen-forming species were recorded together with lichenicolous fungi and non-lichenised fungi normally included in lichen surveys (e.g. Mycoporum spp.).

Specimens were identified to species using standard microscopic techniques and HPTLC (Arup et al. 1993) where necessary. Photobionts in each lichen were recordedclassified as either Trentepohliaceae ( $\mathrm{Tr}$ ), green coccal Chlorophyta $(\mathrm{gCl})$ or absent (NL) and mean frequency calculated for each plot (Table 2). No cyanobacteria associated lichens were observed in the randomised sampling in this study. Species of high conservation value (Woods and Coppins 2012) were distinguished as notables and for each plot the total number of epiphytic species was recorded and the number of notable species given. 
Table 2 Environmental data for each plot

\begin{tabular}{|c|c|c|c|c|c|c|c|c|c|}
\hline Site name & $\begin{array}{l}\text { Site } \\
\text { code }\end{array}$ & $\begin{array}{l}\text { Forest } \\
\text { type }\end{array}$ & Isol & $\begin{array}{l}\text { Log } \\
\text { fragment }\end{array}$ & $\begin{array}{l}\text { Avg. } \\
\text { dbh } \\
(\mathrm{m})\end{array}$ & $\begin{array}{l}\text { Epiphytic } \\
\text { species }\end{array}$ & Notable species & $\begin{array}{l}\text { Freq } \\
\mathrm{gCL}\end{array}$ & $\begin{array}{l}\text { Freq } \\
\operatorname{Tr}\end{array}$ \\
\hline $\begin{array}{l}\text { Bramshaw } \\
\text { Wood }\end{array}$ & BSW & $\mathrm{a}$ & $\mathrm{c}$ & 2.31 & 2.591 & 48 & 18 & 24.5 & 44 \\
\hline Berry Wood & BWW & a & $\mathrm{c}$ & 1.81 & 2.894 & 46 & 9 & 17.17 & 29.42 \\
\hline $\begin{array}{l}\text { Hincheslea } \\
\text { Wood }\end{array}$ & HLW & $\mathrm{a}$ & is & 1.49 & 2.22 & 46 & 10 & 16.25 & 48.33 \\
\hline $\begin{array}{l}\text { Mark Ash } \\
\text { Wood }\end{array}$ & MAW & a & $\mathrm{c}$ & 1.94 & 1.95 & 33 & 7 & 17.58 & 23.25 \\
\hline $\begin{array}{l}\text { Plain Heath } \\
\text { Woodland }\end{array}$ & PHW & $\mathrm{a}$ & is & 0.60 & 1.692 & 31 & 8 & 13.33 & 15.67 \\
\hline $\begin{array}{l}\text { Red Shoot } \\
\text { Wood }\end{array}$ & RSW & a & is & 2.20 & 2.392 & 34 & 8 & 14.17 & 38.5 \\
\hline Shave Wood & SWW & $\mathrm{a}$ & $\mathrm{c}$ & 1.97 & 2.51 & 52 & 9 & 20.58 & 36.08 \\
\hline $\begin{array}{r}\text { Tantany } \\
\text { Wood }\end{array}$ & TTW & $\mathrm{a}$ & $\mathrm{c}$ & 2.39 & 1.81 & 43 & 12 & 27.17 & 36.92 \\
\hline $\begin{array}{r}\text { Whitley } \\
\text { Wood }\end{array}$ & WWW & a & $\mathrm{c}$ & 2.43 & 1.91 & 42 & 16 & 19.5 & 32.08 \\
\hline $\begin{array}{l}\text { Highland } \\
\text { Water } \\
\text { Inclosure }\end{array}$ & HWI & $\mathrm{p}$ & $\mathrm{c}$ & 2.64 & 1.77 & 15 & 9 & 13.83 & 17.75 \\
\hline $\begin{array}{l}\text { New Park } \\
\text { Plantation }\end{array}$ & NPI & $\mathrm{p}$ & $\mathrm{c}$ & 2.2 & 1.78 & 47 & 4 & 30.92 & 25.42 \\
\hline $\begin{array}{l}\text { Ocknell } \\
\text { Inclosure }\end{array}$ & OII & $\mathrm{p}$ & $\mathrm{c}$ & 1.83 & 2.02 & 26 & 7 & 13.67 & 19.17 \\
\hline $\begin{array}{l}\text { South } \\
\text { Bentley } \\
\text { Inclosure }\end{array}$ & SBI & $\mathrm{p}$ & $\mathrm{c}$ & 1.32 & 1.92 & 19 & 5 & 12.08 & 19.75 \\
\hline $\begin{array}{l}\text { South } \\
\text { Oakley } \\
\text { Inclosure }\end{array}$ & SOI & $\mathrm{p}$ & $\mathrm{c}$ & 2.77 & 1.77 & 26 & 2 & 24 & 20.25 \\
\hline $\begin{array}{l}\text { Set Thorns } \\
\text { Inclosure }\end{array}$ & STI & $\mathrm{p}$ & is & 2.11 & 2.32 & 28 & 2 & 33.58 & 10.08 \\
\hline
\end{tabular}

Forest type $a$ ancient woodland, $p$ plantation; is isolation, $c$ core woodland, $A v g . d b h(m)$ average dbh (m), epiphytic species total number of epiphytic species in plot, notable species total number of notable species in plot, Freq $g C L$ mean frequency of lichens with coccal green Chlorophyta photobiont, Freq $\operatorname{Tr}$ mean frequency of lichens with trentepohlioid photobiont

\section{Environmental variables between plots}

Plot age was defined from published records (Sanderson 2007; Carpenter et al. 2012), with ancient woodland plots being assigned an arbitrary (large) age of 500 years (Table 1). Plots were defined as old growth or plantation and as isolated or within the central block of woodland (giving four categories: old growth core, old growth isolated, plantation core, plantation isolated). Isolation and fragmentation was calculated for each of the plots using mapping data supplied by the Forestry Commission in ArcMap10 (Carpenter et al. 2012). The size of the habitat fragments in which each of the plots was located was calculated, taking into consideration continuous and contiguous habitats and using an area calculation 
procedure to generate woodland fragment sizes for each plot (Carpenter et al. 2012). We $\log$ transformed fragment size for all analyses ("Logfrag”).

\section{Analysis}

We examined two related sets of dependent variables, using univariate and multivariate approaches (ordination).

\section{Univariate analysis}

Correlates of species density were explored using a generalised linear mixed model, with a Poisson error structure and a log-link function. Analyses were conducted in $\mathrm{R}$ for the following subsets of the data: (1) the entire dataset, with all trees included; (2) Fagus trees only; (3) Quercus trees only. "Plot" was defined as a random factor, all of the other explanatory factors were fixed factors. This allows comparisons between plot-level patterns while taking into account the variation within plots. Best-parameterised models were chosen using the dropl function (R Core Team 2016). A full model was run and then dropl was used to show the Aikake information criterion (AIC) of each model with one variable dropped. If the AIC of any single-dropped model was lower than the AIC without a dropped variable, that variable was dropped. This process was continued until the AIC of the model was lower than that with any dropped variables. In most cases this only meant dropping one or two variables from the model.

\section{Multivariate analysis}

We undertook a constrained ordination analysis in order to assess the relationship between our putative explanatory variables and the species composition of the lichens. Following Lepš and Šmilauer (2003), we undertook an initial unconstrained ordination analysis using a DCA with Hill's scaling within CANOCO 5, which gave us the gradient length of the first axis of the analysis. This was more than four standard deviation units of species turnover (4.4. SD units) and so a unimodal constrained ordination method, canonical correspondence analysis (CCA), is most appropriate. We also followed Lepš and Šmilauer (2003) in comparing the eigenvalues of axes of unconstrained (CA) and constrained analyses (CCA), in order to check that they had comparable scores, and so that we were not missing major sources of variation.

A Monte Carlo permutation test gave us a model of how the explanatory variables were associated with lichen species composition. $P$ values were calculated by permuting only between sites (not within sites) to give accurate between-plots values (i.e. taking into account the split plot design, with trees nested within plots). We only show explanatory variables with significant associations as calculated by the Monte Carlo test in the ordination figures. Simple permutation test results—with each variable tested separately-are shown in the supplementary data.

A first, subjective, examination of the CCA results suggested a number of clear clusters in the plot ordination space. To examine this further, we performed a cluster analysis on the scores for the CCA analysis, to confirm that they were separated from each other. The clusters were derived using the agnes command in the $\mathrm{R}$ package cluster, which first calculates the pairwise Euclidean distances between plots in ordination space and then 
assigns plots to clusters using the UPGMA (average distance between clusters) method (Maechler et al. 2016). We did not attempt any probabilistic statistical tests of these clusters to avoid P-hacking (Motulsky 2014).

\section{Results}

Epiphytic lichens were surveyed on 180 trees. In total, we recorded 131 species of epiphytic lichens including lichenicolous fungi and non lichenised Mycoporum spp. in the quadrats, of which 125 species were recorded in old growth plots and 79 in the plantation enclosures (Appendix). Lichen species density on trunks of tree species was as follows: Quercus supported a total of 112 species on 86 trees with a mean of 10.6 per tree (SD 4.6), Fagus a total of 84 species on 55 trees with a mean of 9.5 per tree (SD 4.3) and Ilex a total of 41 species on 32 trees with a mean of 8.5 per tree (SD 4.5).

\section{Univariate analysis}

Epiphytic lichen species density on trees at the plot level shows a significant difference between the old growth woodland plots and the plantation plots in that mean species density is higher in the old growth woodland plots than in the plantations (Table 3). Between the dominant trees, species density is highest on oak in the old growth woodlands $>500$ years and in plots which are located in forest areas which are not fragmented or isolated. However where a plantation plot is adjacent to old growth woodland (e.g. NPI is adjacent to WWW) the epiphytic species density is almost as high, but the number of notable species is considerably lower in the plantation plot (Fig. 2).

The finding of the mixed models were contrasting for the $\mathrm{Tr}$ and $\mathrm{gCl}$ photobiont based lichen groups in the oak subsample, with age being negatively correlated with species density in the $\mathrm{gCl}$ group and positively associated in the $\mathrm{Tr}$ group (Table 3 ).

Table 3 Summary of results of mixed model GLMs (generalized linear model) in isolated and core plots in plantation and old growth forest: $\mathrm{z}$ values = estimate of difference in standard deviations from reference means, "-ve" and "+ve" refers to the prefix of the model estimates

\begin{tabular}{|c|c|c|c|}
\hline & All groups & $\mathrm{gCl}$ photobiont & Tr photobiont \\
\hline All & $\begin{array}{l}\text { Quercus }+3.5^{* * *} \\
\text { Plantation core }-2.6^{*} \\
\text { Plantation isolated }-2.5^{*}\end{array}$ & $\begin{array}{l}\text { Age }-4.2 * * * \\
\text { Ilex }-4.9 * * * \\
\text { Plantation core }-4.7 * * * \\
\text { Plantation isolated }-3.7 * * *\end{array}$ & $\begin{array}{l}\text { Quercus }+3.3 * * * \\
\text { Ilex }+4.1^{* * *} \\
\text { Log-frag }+3.7 * * * \\
\text { DBH }+3.13 * * *\end{array}$ \\
\hline Fagus & Plantation core $-2.5^{*}$ & $\begin{array}{l}\text { Plantation, core }-2.7 * * * \\
\text { Age }-2.4 * *\end{array}$ & $\begin{array}{l}\text { Plantation core }-2.6^{*} \\
\text { Plantation isolated }-2.3 *\end{array}$ \\
\hline Quercus & $\begin{array}{l}\text { Age }-3.1 * * \\
\text { Old growth isolated }-3.3 * * * \\
\text { Plantation core }-4.5 * * * \\
\text { Plantation peripheral }-4.2 * * *\end{array}$ & $\begin{array}{l}\text { Age }-4.0 * * * \\
\text { Plantation core }-4.4 * * * \\
\text { Plantation isolated }-3.7 * * *\end{array}$ & $\begin{array}{l}\text { Age }+2.2 * \\
\text { Log-frag }+2.9 * * \\
\mathrm{DBH}+2.2^{*}\end{array}$ \\
\hline
\end{tabular}

*** $\mathrm{P}=0.001-0.0001, * * \mathrm{P}=>0.001-<0.01, * \mathrm{P}=0.01-0.05$ 
Fig. 2 Total number of epiphytic lichens plotted against total number of notable species in each plot in old growth (filled diamond) and plantations (open square). Codes used for sites in Tables 1 and 2

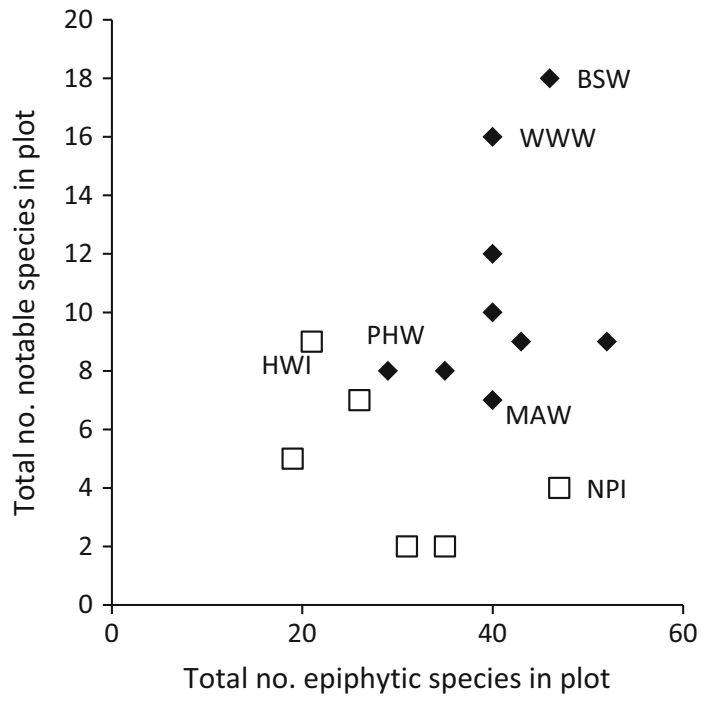

Table 4 Monte Carlo tests within the CCA, based on 999 permutations for all explanatory variables

Pseudo-F is the Monte Carlo permutation equivalent of a standard F statistic

Simple probability of the explanatory variable included alone. Significant factors marked $* \mathrm{P}=$ probability $<0.05$

\begin{tabular}{llc}
\hline Name & Pseudo-F & $\mathrm{P}$ \\
\hline Ilex* & 4.6 & $\leq 0.001$ \\
Quercus* $^{*}$ & 3.6 & $\leq 0.001$ \\
Fagus* $^{*}$ Dbh* & 2.7 & $\leq 0.001$ \\
Betula* & 2.7 & $\leq 0.001$ \\
Isolation* & 2.6 & 0.027 \\
Age* & 2.5 & 0.02 \\
logfrag & 2.4 & 0.019 \\
Sorbus & 1.8 & 0.337 \\
Castaneus & 1.6 & 0.187 \\
Acer & 1.1 & 0.348 \\
\hline
\end{tabular}

\section{Multivariate analysis}

An initial unconstrained ordination gave the following results: axis 1 eigenvalue $=0.46$, axis 2 eigenvalue $=0.429$. The constrained analysis was able to explain just over half of this total variation: constrained axis 1 eigenvalue $=0.30$, constrained axis 2 eigenvalue $=0.21$. The pseudocanonical correlations between explanatory variables and the main ordination axes were high: axis $1=0.91$, axis $2=0.79$.

A summary of the results of the Monte Carlo permutation test are shown in Table 4 . The significant continuous variables include plot age and dbh (tree girth) and nominal variables include the association with tree species Quercus, Fagus, Ilex and Betula. It also includes isolation as opposed to extensive core sites. We have distinguished four different clusters (Fig. 3a): (A) the old growth woodlands with dominant oaks of increasing age/dbh, (B) old growth woodlands with a high proportion of beech and including older plantations $>240$ years old, (C) isolated plots PHW and HLW distinguished by their lichen 
Fig. 3 a CCA biplot of the distribution of epiphytic lichen communities in relation to: continuous variables—dbh (tree girth), age of plot—red arrows; nominal variables (tree genus) open triangle; isolation filled diamond; distribution of plots open circle with clusters $A-D$ shown. b Dendrogram of clusters within CCA analysis, based on axis 1 and axis 2 (biplot) positions in CCA ordination space showing the separation of plots in cluster $D$ from all other plots at the highest level, the distinction of old growth sites on Quercus in cluster $A$ from other sites, and overlapping plantation and old growth sites with Fagus present in cluster $B$, a cluster $C$ associated with isolation and Ilex as a substrate. Height is Euclidean distance in the arbitrary units of the ordination space. (Color figure online)

communities on Ilex and their isolation, (D) the younger plantations 200 years or less. The dendrogram from the cluster analysis (Fig. 3b) reinforces the difference between the plantations (SOI, STI and NPI) in cluster D and the old growth plots in cluster A.

The CCA species-environment biplot (Fig. 4) shows the relation of the most frequently occurring ( $>4 \%$ frequency) lichen species to the variables identified in Fig. 3a and their association with the clusters identified in Fig. 3b (the complete list is in the Appendix). Cluster A is associated with the continuous variables increasing age and dbh in the old growth forest. Clusters A, B and C are associated with crustose species that contain a trentepohlioid photobiont, (see table of species in Appendix) while cluster D is characterised by species with a coccoid green Chlorophyta photobiont including lichens with more complex growth forms such as Parmotrema perlatum. Within the groups distinguished by a trentepohlioid photobiont cluster A includes indicators of ecological continuity (NIEC) such as Cresponea premnea, and additional notable species of Porina and Schismatomma. Cluster B instead is distiguished by widespread species with fewer NIEC and notable species. Cluster $\mathrm{C}$ is distinguished by crustose species with Trentepohliaceae photobionts associated with smooth barked Ilex. They include more widespread species Graphis scripta, Porina leptalea and Opegrapha vulgata together with non-lichenised NIEC species of Mycoporum.

Our results indicate that even 300 year old plantations do not support as many specialist epiphytic species as the old growth woodland. The plots with highest numbers of notable species of old growth forest are all within parts of the forest within the two original main blocks of woodland with an ecological continuity greater than 500 years.

\section{Discussion}

The New Forest is one of the few places in lowland Europe where an extensive area of deciduous forest and heathland has remained over centuries. The woodland has been under wood pasture management for more than a thousand years, creating a mosaic of conditions across ca. 56,000 hectares of landscape, of which $>3000$ hectares are designated as ancient unenclosed pasture woodland or old growth forest (Tubbs 2001). Our findings that plots within the old growth forest have a higher epiphytic lichen species density and higher numbers of notable species than plantation plots of similar deciduous species agree with other findings across a range of forest types in Europe (Brunialti et al. 2013; Ellis 2013; Fritz et al. 2008; Johansson and Ehrlén 2003; Johansson et al. 2013; Rose 1976). Increasing species density is associated with increasing structural heterogeneity that has developed over time at tree-and stand-level in old growth forests, where there are trees at all stages of life and death (Ellis 2013; Dittrich et al. 2013). The relationship between woodland age, structural diversity and specialist lichen communities has been investigated in broad leaved forests in Sweden where the negative effects of fragmentation and loss of substrate on specialist lichens of old growth forests was demonstrated by Fritz et al. (2008) and Ranius 
(a)

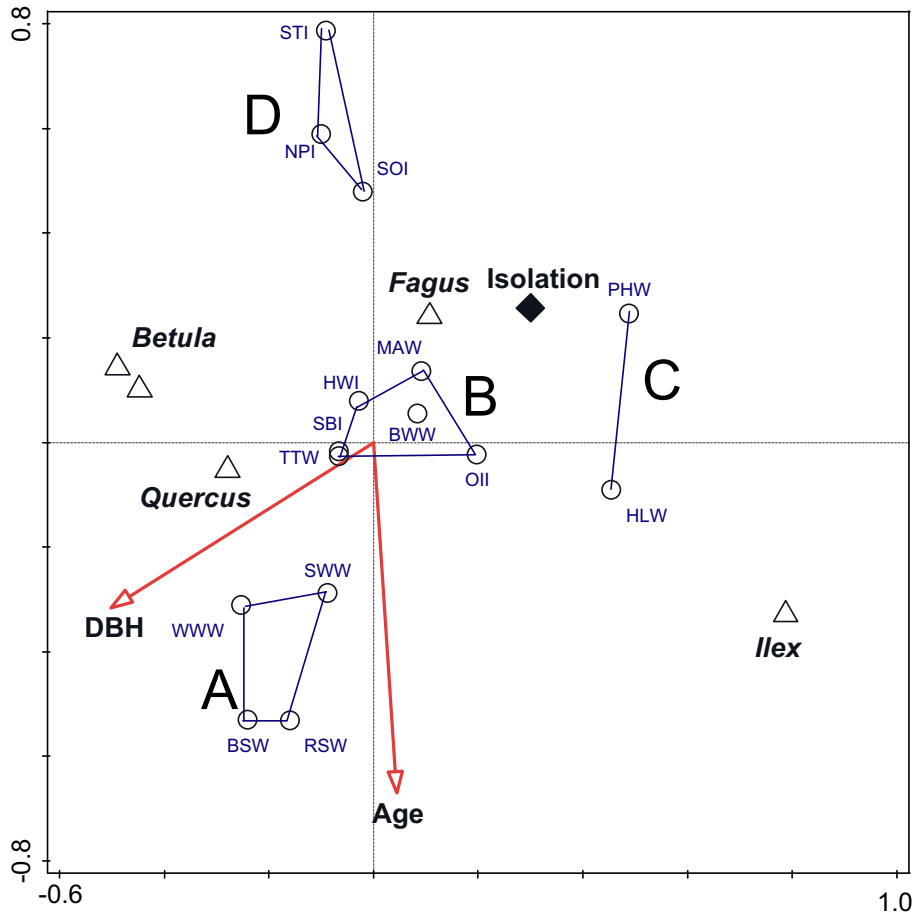

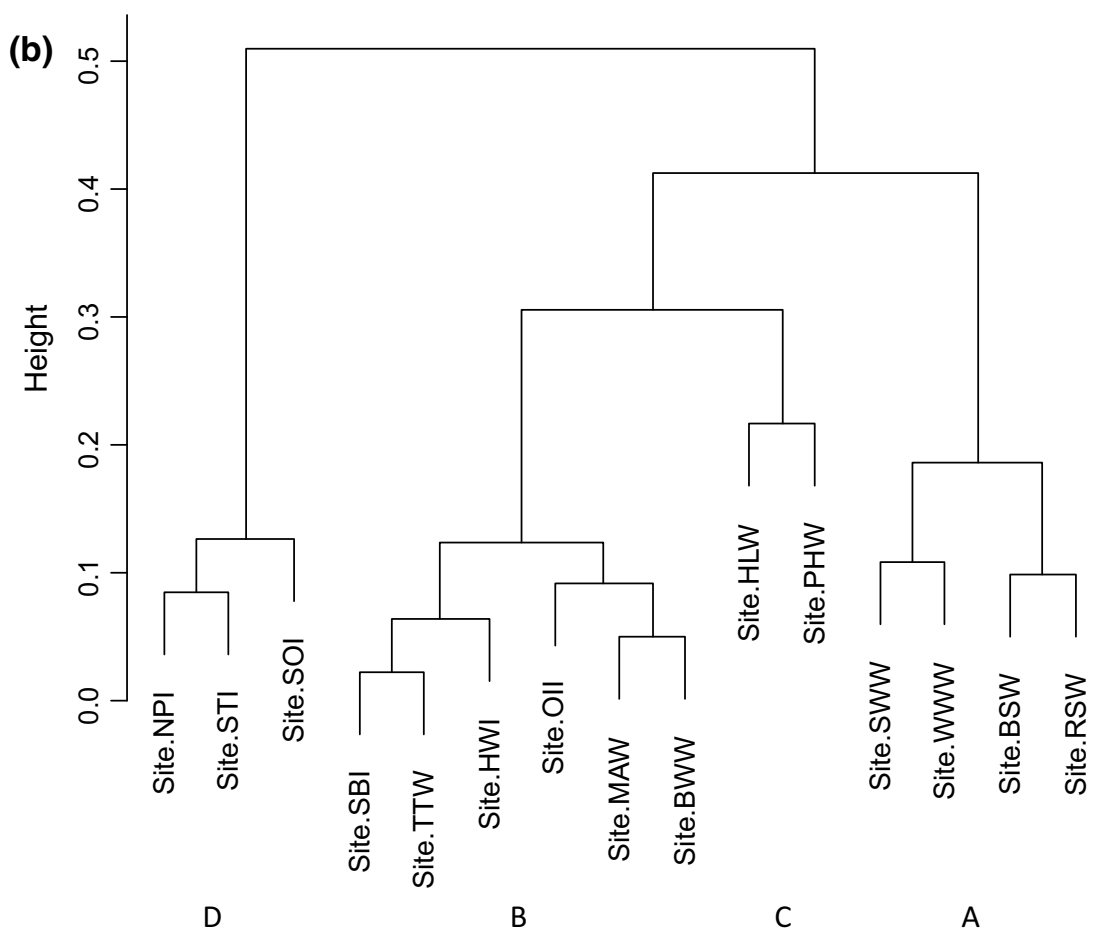




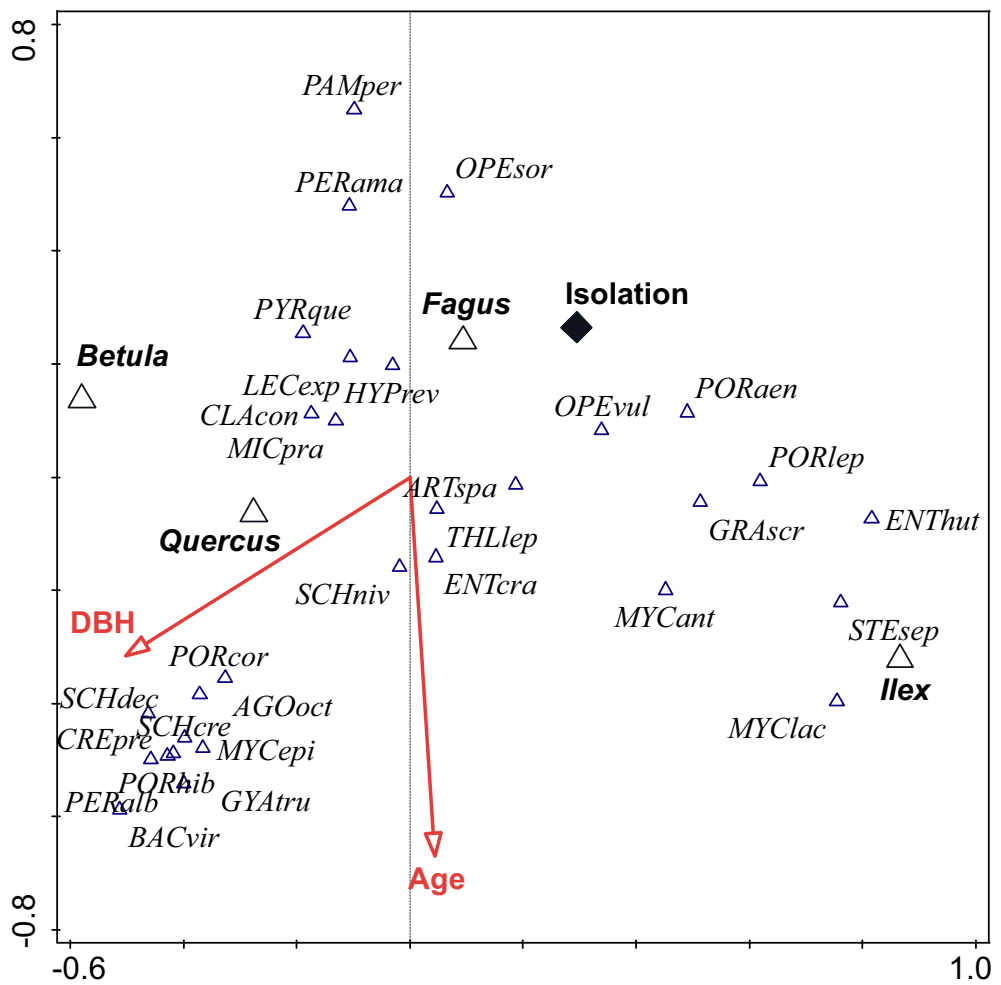

Fig. 4 CCA biplot of the distribution of epiphytic lichen species occurring with $>0.4 \%$ frequency. Species codes including photobiont and \% frequency in old growth plots and plantations in Table 5 in Appendix

et al. (2008), but these studies did not include plantations or plots of a comparable age to those found in the New Forest.

\section{Epiphytic indicators of ecological continuity and conservation value}

The CCA identifies lichen species associated with Quercus, Fagus, Betula and Ilex trees in our plots. Most of the lichens identified in the CCA (Fig. 4; Appendix) as characteristic of cluster A, associated with Quercus, and with increasing dbh and plot age, are also established as indicators of ecological continuity in broad leaved deciduous woodlands of lowland England (Coppins and Coppins 2002). This group is widely distributed on ancient oak trees in the New Forest where the rough ridged bark and lower bark $\mathrm{pH}$ provides a different structure and chemistry from the smooth bark of both Fagus and Ilex. These ancient trees support a greater number of notable lichen species that are indicators of ecological continuity, as well as niche specialists of high conservation value (Woods and Coppins 2012). The New Forest is one of the few places in Britain where Fagus sylvatica is native, which is more characteristic of Central Europe (Rose and James 1974; Fritz et al. 2008). In Britain Fagus is often rather poor in lichen species but in the New Forest it supports a suite of epiphytic lichens that are rare elsewhere in Britain. Ilex aquifolium has been maintained to a great age in some parts of the forest by pollarding and is also positively associated with trentepohliod crustose lichen species as well as indicators of ecological continuity, including non lichenised species of Mycoporum (Sanderson 2010). 
The trentepohlioid crusts that distinguish the old growth forest plots in the New Forest include an element that is characteristic of warmer parts of Europe extending to tropical parts of the world, including species of Porina, Enterographa and Cresponea (McCarthy 2003; Sparrius 2004; Egea and Torrente 1994). These species are rare or absent from much of the UK and reflect the special bioclimatic position of the New Forest in the UK.

\section{External factors}

How much have plots in these sites been influenced by external factors such as changing patters of management and by atmospheric pollution in a densely populated part of southern England?

\section{Management}

Extensive grazing of common land by a range of species including deer, ponies and cattle has been an important factor in maintaining a wood pasture environment over large areas of the New Forest that has continued for centuries since it was declared a Royal Hunting Forest (Tubbs 2001). Today it is managed extensively by the commoners as wood pasture and supports a range of habitats and species associated with ecological continuity (Sanderson 2010). Grazing is managed extensively by the commoners and although plantations have been formerly enclosed they are now openly grazed under a wood pasture regime providing a good habitat for epiphytic lichens (Sanderson 2010). This will encourage further development of epiphytic lichen communities in the plantations, which are now maintained as wood pasture.

\section{Air pollution}

The New Forest lies between the cities of Bournemouth and Southampton, with a formerly active oil fired power station at Fawley on the Eastern edge of the Forest and numerous arterial roads bisecting the forest. One of the features of our survey is the low frequency of macrolichens and the absence of those with cyanobacterial photobionts, species that are characteristic of old growth forests and highly sensitive to air pollutants (Rose and James 1974) and which were formerly widespread in the forest (Crombie 1894; Rose and James 1974). Due to their reliance on liquid water uptake instead of water vapour alone (Lange and Kilian 1985; Lange and Ziegler 1986; Lange et al. 1986), their thalli are usually more or less hydrophilic, while many of the present lichens with Chlorophyta photobionts in the New Forest contain hydrophobic extrolites that prevent wetting during high episodes of wet $\mathrm{SO}_{2}$ deposition (Hauck et al. 2008). The absence of nitrophytic species (e.g. species of Xanthoria and Physcia) in our plots suggests that levels of atmospheric nitrogen compounds are at present low despite the major roads that bisect the forest. None of our sites were adjacent to the main arterial roads that cross the Forest so we cannot comment on this, but elsewhere there is plenty of evidence to show loss of sensitive species and an increase in nitrophytic species in sites adjacent to main roads (Davies et al. 2007; Larsen et al. 2007) so this is a potential cause for future change in lichen communities.

\section{Concluding remarks}

The results of this survey of oak-dominated woodlands in the New Forest National Park demonstrate a positive association of Trentepohliaceae photobionts to increasing plot age 
and negative response to fragmentation and isolation. Lichens with other Chlorophyta photobionts (including those associated with common genera Trebouxia and Asterochloris) are negatively associated with increasing plot age. This difference is probably linked to physiological processes which are generally poorly studied for Trentepohliaceae-associated lichens. Trentepohliaceae are often the dominant photobiont group in the wet tropics and our results show that they also contribute a surprisingly high percentage of notable and threatened species in the old growth forests in this temperate lowland forest in the UK. The fungal components in these associations span various families and this confirms a constraining role of the photobiont for many species of conservation concern in the New Forest and more widely in Britain and in temperate Europe (Woods and Coppins 2012; Schöller 1997). More research on the genetic diversity of lichenised Trentepohliaceae taxa from those occurring in pioneer lichens to old growth specialists in temperate forests, as well as in situ studies on microclimatic niches and ecophysiological performance of different photobiont groups, are needed to enhance our understanding of the underlying processes of the observed patterns and their implications for conservation practice.

Acknowledgements This work forms part of the 'New Forest Quantitative Inventory' and was funded by a Grant from the NHM's Annual Fund. We thank the Forestry Commission for permission to work in the National Park. Thanks to two anonymous reviewers for comments on the manuscript.

Open Access This article is distributed under the terms of the Creative Commons Attribution 4.0 International License (http://creativecommons.org/licenses/by/4.0/), which permits unrestricted use, distribution, and reproduction in any medium, provided you give appropriate credit to the original author(s) and the source, provide a link to the Creative Commons license, and indicate if changes were made.

\section{Appendix}

See Table 5 .

Table 5 Species included in the analyses

\begin{tabular}{lllll}
\hline Species name & Species code & Algae & \%Freq T-pl & \%Freq T-OGW \\
\hline Abrothallus microspermus & ABRmic & lichenic & 0 & 0.02 \\
Acrocordia gemmata & ACRgem & $\operatorname{Tr}$ & 0 & 0.01 \\
Agonimia octospora & AGOoct & $\operatorname{Tr}$ & 1.18 & 0.75 \\
Anisomeridium biforme & ANIbif & $\operatorname{Tr}$ & 0.14 & 0.13 \\
Anisomeridium polypori & ANIpol & $\operatorname{Tr}$ & 0.07 & 0.19 \\
Anisomeridium ranunculosporum $*$ & ANIran & $\operatorname{Tr}$ & 9.44 & 2.32 \\
Arthonia astroidestera* & ARTast & $\operatorname{Tr}$ & 0 & 0.01 \\
Arthonia didyma & ARTdid & $\operatorname{Tr}$ & 0.83 & 0.02 \\
Arthonia ilicina $*$ & ARTili & $\operatorname{Tr}$ & 0 & 0.01 \\
Arthonia invadens & ARTinv & $\operatorname{Tr}$ & 0.76 & 0.68 \\
Arthonia radiata & ARTrad & $\operatorname{Tr}$ & 0.14 & 0 \\
Arthonia spadicea & ARTspa & $\operatorname{Tr}$ & 6.11 & 2.59 \\
Arthonia vinosa & ARTvin & $\operatorname{Tr}$ & 2.5 & 0 \\
Bacidia biatorina $*$ & BACbia & $\mathrm{gCl}$ & 0 & 0.06 \\
Bacidia incompta & BACinc & $\mathrm{gCl}$ & 0 & 0.03 \\
\hline
\end{tabular}


Table 5 continued

\begin{tabular}{|c|c|c|c|c|}
\hline Species name & Species code & Algae & $\%$ Freq T-pl & $\%$ Freq T-OGW \\
\hline Bacidia viridifarinosa & $\underline{B A C v i r}$ & $\mathrm{gCl}$ & 0 & 0.06 \\
\hline Bactrospora corticola & BACcor & $\operatorname{Tr}$ & 0 & 0.04 \\
\hline Biatora britannica & BIAbri & $\mathrm{gCl}$ & 0 & 0.02 \\
\hline Calicium salicinum & CALsal & $\mathrm{gCl}$ & 0 & 0.02 \\
\hline Caloplaca obscurella & CALobs & $\mathrm{gCl}$ & 0.14 & 0.04 \\
\hline Candelariella reflexa & CANref & $\mathrm{gCl}$ & 0.42 & 0.01 \\
\hline Catinaria atropurpurea* & CATatr & $\mathrm{gCl}$ & 0 & 0.01 \\
\hline Chaenotheca brachypoda* & CHAbra & $\mathrm{gCl}$ & 0.21 & 0 \\
\hline Chaenotheca brunneola* & CHAbru & $\mathrm{gCl}$ & 0 & 0.05 \\
\hline Chaenotheca hispidula* & CHAhis & $\mathrm{gCl}$ & 0 & 0.01 \\
\hline Chaenotheca trichialis* & CHAtri & $\mathrm{gCl}$ & 0 & 0.04 \\
\hline Chaenothecopsis nigra & CHAnig & $\mathrm{gCl}$ & 0 & 0.03 \\
\hline Chrysothrix candelaris & CHRcan & $\mathrm{gCl}$ & 0.97 & 0.04 \\
\hline Chrysothrix flavovirens & CHRfla & $\mathrm{gCl}$ & 5.9 & 0.5 \\
\hline Cladonia coniocraea & CLAcon & $\mathrm{gCl}$ & 9.65 & 2.21 \\
\hline Cladonia digitata & CLAdig & $\mathrm{gCl}$ & 0.07 & 0.04 \\
\hline Cladonia polydactyla & CLApol & $\mathrm{gCl}$ & 3.96 & 0.32 \\
\hline Cladonia pyxidata & CLApyx & $\mathrm{gCl}$ & 0 & 0.1 \\
\hline Cliostomum flavidulum & CLIfla & $\mathrm{gCl}$ & 0.56 & 0.17 \\
\hline Cliostomum griffithii & CLIgri & $\mathrm{gCl}$ & 1.39 & 0.39 \\
\hline Cresponea premnea* & CREpre & $\operatorname{Tr}$ & 0 & 0.3 \\
\hline Dimerella pineti & DIMpin & $\operatorname{Tr}$ & 0.21 & 0.35 \\
\hline Enterographa crassa & $\underline{\text { ENTcra }}$ & $\operatorname{Tr}$ & 4.58 & 3.33 \\
\hline Enterographa hutchinsiae & ENThut & $\operatorname{Tr}$ & 0 & 0.09 \\
\hline Enterographa sorediata* & ENTsor & $\operatorname{Tr}$ & 0 & 0.06 \\
\hline Evernia prunastri & EVEpru & $\mathrm{gCl}$ & 0.21 & 0.01 \\
\hline Flavoparmelia caperata & FLAcap & $\mathrm{gCl}$ & 1.32 & 0.2 \\
\hline Graphis elegans & GRAele & $\operatorname{Tr}$ & 4.1 & 0.22 \\
\hline Graphis scripta & GRAscr & $\operatorname{Tr}$ & 1.74 & 0.63 \\
\hline Gyalecta truncigena & GYAtru & $\operatorname{Tr}$ & 0 & 0.04 \\
\hline Hypocenomyce scalaris & HYPsca & $\operatorname{Tr}$ & 0 & 0.01 \\
\hline Hypogymnia physodes & HYPphy & $\mathrm{gCl}$ & 0.07 & 0.09 \\
\hline Hypotrachyna revoluta & HYPrev & $\mathrm{gCl}$ & 1.94 & 0.55 \\
\hline Jamesiella anastomosans & JAMana & $\mathrm{gCl}$ & 0 & 0.02 \\
\hline Lecanactis abietina & $\underline{\text { LECabi }}$ & $\operatorname{Tr}$ & 12.29 & 2.52 \\
\hline Lecanographa lyncea* & LEClyn & $\operatorname{Tr}$ & 0 & 0.04 \\
\hline Lecanora chlarotera & LECchl & $\mathrm{gCl}$ & 0.49 & 0.06 \\
\hline Lecanora confusa & LECcon & $\mathrm{gCl}$ & 0.14 & 0.01 \\
\hline Lecanora expallens & LECexp & $\mathrm{gCl}$ & 7.92 & 0.86 \\
\hline Lecidea doliiformis & $\underline{\text { LECdol }}$ & $\mathrm{gCl}$ & 0 & 0.1 \\
\hline Lepraria incana & LEPinc & $\mathrm{gCl}$ & 5.56 & 0.39 \\
\hline Lepraria cf. ecorticata & LEPeco & $\mathrm{gCl}$ & 0.56 & 0.09 \\
\hline Lepraria lobificans & LEPlob & $\mathrm{gCl}$ & 50.69 & 10.33 \\
\hline
\end{tabular}


Table 5 continued

\begin{tabular}{|c|c|c|c|c|}
\hline Species name & Species code & Algae & $\%$ Freq T-pl & $\%$ Freq T-OGW \\
\hline Lepraria sp. & LEPsp & $\mathrm{gCl}$ & 0.28 & 0.32 \\
\hline Lepraria umbricola & LEPumb & $\mathrm{gCl}$ & 0 & 0.13 \\
\hline Loxospora elatina* & LOXela & $\mathrm{gCl}$ & 1.6 & 0.68 \\
\hline Megalaria pulverea & MEGpul & $\mathrm{gCl}$ & 0.07 & 0.07 \\
\hline Melanelixia fuliginosa subsp glabratula & MELful & $\mathrm{gCl}$ & 5.63 & 0.06 \\
\hline Melaspilea amota & MELamo & $\operatorname{Tr}$ & 0 & 0.1 \\
\hline Melaspilea ochrothalamia & MELoch & $\operatorname{Tr}$ & 0.42 & 0.17 \\
\hline Micarea peliocarpa & MICpel & $\mathrm{gCl}$ & 0.14 & 0.12 \\
\hline Micarea prasina & MICpra & $\mathrm{gCl}$ & 25.83 & 3.68 \\
\hline Micarea pycnidiophora & MICpyc & $\mathrm{gCl}$ & 0.76 & 0.81 \\
\hline Milospium graphideorum & MILgra & lichenic & 0 & 0.02 \\
\hline Mycobilimbia epixanthoides* & MYCepi & $\mathrm{gCl}$ & 0 & 0.18 \\
\hline Mycoblastus caesius & MYCcae & $\mathrm{gCl}$ & 5 & 0.3 \\
\hline Mycoblastus fucatus & MYCfuc & $\mathrm{gCl}$ & 0 & 0.05 \\
\hline Mycoporum antecellans* & MYCant & NL & 0.28 & 0.25 \\
\hline Mycoporum lacteum* & MYClac & NL & 0.14 & 0.56 \\
\hline Normandina pulchella & NORpul & $\mathrm{gCl}$ & 2.5 & 0.29 \\
\hline Ochrolechia subviridis & OCHsub & $\mathrm{gCl}$ & 0 & 0.03 \\
\hline Opegrapha atra & OPEatr & $\operatorname{Tr}$ & 0.14 & 0.01 \\
\hline Opegrapha corticola* & OPEcor & $\operatorname{Tr}$ & 0 & 0.04 \\
\hline Opegrapha fumosa & OPEfum & $\operatorname{Tr}$ & 0 & 0.06 \\
\hline Opegrapha multipuncta & OPEmul & $\operatorname{Tr}$ & 0 & 0.18 \\
\hline Opegrapha ochrocheila & OPEoch & $\operatorname{Tr}$ & 0 & 0.03 \\
\hline Opegrapha sorediifera & OPEsor & $\operatorname{Tr}$ & 1.25 & 0.07 \\
\hline Opegrapha varia & OPEvar & $\operatorname{Tr}$ & 0.28 & 0.12 \\
\hline Opegrapha vulgata & OPEvul & $\operatorname{Tr}$ & 4.58 & 1.21 \\
\hline Pachyphiale carneola* & PACcar & $\operatorname{Tr}$ & 0.9 & 0.76 \\
\hline Parmelia saxatilis & PACsax & $\mathrm{gCl}$ & 0.42 & 0.06 \\
\hline Parmelinopsis horrescens & PARhor & $\mathrm{gCl}$ & 0 & 0.1 \\
\hline Parmeliopsis hyperopta & PARhyp & $\mathrm{gCl}$ & 0 & 0.03 \\
\hline Parmotrema perlatum & PAMper & $\mathrm{gCl}$ & 0.69 & 0.04 \\
\hline Pertusaria albescens & $\underline{\text { PERalb }}$ & $\mathrm{gCl}$ & 0 & 0.05 \\
\hline Pertusaria amara & PERama & $\mathrm{gCl}$ & 2.57 & 0.1 \\
\hline Pertusaria amara $f$. pulvinata & PERvpul & $\mathrm{gCl}$ & 0 & 0.06 \\
\hline Pertusaria hemispherica & PERhem & $\mathrm{gCl}$ & 0.07 & 0 \\
\hline Pertusaria hymenea & PERhym & $\mathrm{gCl}$ & 1.6 & 0.38 \\
\hline Pertusaria leioplaca & PERlei & $\mathrm{gCl}$ & 0.83 & 0.12 \\
\hline Pertusaria multipuncta* & PERmul & $\mathrm{gCl}$ & 0 & 0.04 \\
\hline Pertusaria pertusa & $\underline{\text { PERper }}$ & $\mathrm{gCl}$ & 0.69 & 0.13 \\
\hline Phaeographis dendritica* & PHAden & $\operatorname{Tr}$ & 1.11 & 0.17 \\
\hline Phaeographis inusta & PHAinu & $\operatorname{Tr}$ & 0.35 & 0 \\
\hline Phaeographis lyellii & PHAlye & $\operatorname{Tr}$ & 0.07 & 0 \\
\hline Phlyctis argena & PHCarg & $\mathrm{gCl}$ & 2.71 & 0.45 \\
\hline
\end{tabular}


Table 5 continued

\begin{tabular}{|c|c|c|c|c|}
\hline Species name & Species code & Algae & $\%$ Freq T-pl & $\%$ Freq T-OGW \\
\hline Phyllopsora rosei* & PHLros & $\mathrm{gCl}$ & 0 & 0.01 \\
\hline Physcia tenella & PHSten & $\mathrm{gCl}$ & 0.21 & 0.05 \\
\hline Porina aenea & $\underline{\text { PORaen }}$ & $\operatorname{Tr}$ & 2.15 & 0.48 \\
\hline Porina borreri & PORbor & $\operatorname{Tr}$ & 0 & 0.05 \\
\hline Porina coralloidea* & PORcor & $\operatorname{Tr}$ & 0.14 & 0.27 \\
\hline Porina hibernica* & $\underline{\text { PORhib }}$ & $\operatorname{Tr}$ & 0 & 0.54 \\
\hline Porina leptalea & PORlep & $\operatorname{Tr}$ & 0.49 & 0.36 \\
\hline Porina rosei & PORros & $\operatorname{Tr}$ & 0.28 & 0.19 \\
\hline Psoroglaena stigonemoides & PSOsti & $\operatorname{Tr}$ & 0.76 & 0.03 \\
\hline Pyrenula chlorospila & PYRchl & $\operatorname{Tr}$ & 0 & 0.01 \\
\hline Pyrrhospora quernea & PYRque & $\operatorname{Tr}$ & 3.33 & 0.15 \\
\hline Ramalina farinacea & RAMfar & $\mathrm{gCl}$ & 0.14 & 0 \\
\hline Ramonia chrysophaea & RAMchr & $\operatorname{Tr}$ & 0.9 & 0.04 \\
\hline Raphidicyrtis trichosporella & RHAtri & $\operatorname{Tr}$ & 0 & 0.04 \\
\hline Ropalospora viridis & ROPvir & $\mathrm{gCl}$ & 0 & 0.13 \\
\hline Schismatomma cretaceum & $\underline{\text { SCHcre }}$ & $\operatorname{Tr}$ & 0 & 0.1 \\
\hline Schismatomma decolorans & $\underline{\text { SCHdec }}$ & $\operatorname{Tr}$ & 0 & 0.68 \\
\hline Schismatomma niveum* & $\underline{\text { SCHniv }}$ & $\operatorname{Tr}$ & 3.06 & 3.59 \\
\hline Schismatomma quercicola* & SCHque & $\operatorname{Tr}$ & 7.15 & 2.3 \\
\hline Scoliciosporum pruinosum & SCOpru & $\mathrm{gCl}$ & 6.74 & 0.4 \\
\hline Skyttea nitschkei & SKYnit & lichenic & 0.69 & 0.52 \\
\hline Stenocybe septata & $\underline{\text { STEsep }}$ & NL & 7.22 & 2.98 \\
\hline Strigula taylori & STRtay & $\operatorname{Tr}$ & 0 & 0.18 \\
\hline Taeniolina scripta & TAEscr & lichenic & 0 & 0.02 \\
\hline Thelopsis rubella & THErub & $\operatorname{Tr}$ & 0.21 & 0.45 \\
\hline Thelotrema lepadinum* & THLlep & $\operatorname{Tr}$ & 24.38 & 7.41 \\
\hline Trapelia corticola & TRAcor & $\mathrm{gCl}$ & 0 & 0.12 \\
\hline Trapeliopsis flexиоsa & TRAfle & $\mathrm{gCl}$ & 0.07 & 0.02 \\
\hline Usnea cornuta & USNcor & $\mathrm{gCl}$ & 0.21 & 0.04 \\
\hline Usnea esperantiana & USNesp & $\mathrm{gCl}$ & 0 & 0.01 \\
\hline Total species & 131 & & 79 & 125 \\
\hline
\end{tabular}

* Indicators of ecological continuity (following Coppins and Coppins 2002); species code underlined for species included in Fig. 4; Algae associated photobiont group

Patterns and drivers of lichen species composition in a NW-European lowland deciduous woodland complex $\mathrm{Tr}$ trentepohliaceae, $\mathrm{gCl}$ coccoid green Chlorophyta, $\mathrm{NL}$ absent (non lichenised fungus), lichenic lichenicolous fungus, \% freq T-pl \% frequency in total of quadrats in plantation plots $(\mathrm{N} \mathrm{T-pl}=1440)$, and in old growth plots $O G W(\mathrm{~N}$ T-OGW $=2160)$

\section{References}

Arup U, Ekman S, Lindblom L, Mattsson J-E (1993) High performance thin layer chromatography (HPTLC), an improved technique for screening lichen substances. Lichenologist 25(1):61-71

Brunialti G, Frati L, Loppi S (2013) Fragmentation of Mediterranean oak forests affects the diversity of epiphytic lichens. Nova Hedwigia 96(1-2):265-278 
Candotto CF, Zanelli D, Bertuzzi S, Tretiach M (2015) Desiccation tolerance and lichenization: a case study with the aeroterrestrial microalga Trebouxia sp. (Chlorophyta). Planta 242(2):493-505

Carpenter D, Hammond PM, Sherlock E, Lidgett A, Leigh K, Eggleton P (2012) Biodiversity of soil macrofauna in the New Forest: a benchmark study across a national park landscape. Biodivers Conserv 21:3385-3410

Coppins A, Coppins BJ (2002) Indices of ecological continuity for woodland epiphytic lichen habitats in the British Isles. British Lichen Society, Wimbledon

Crombie JM (1894) A monograph of Lichens found in Britain: being a descriptive catalogue of the species of the British Museum Part I. Order of the Trustees, London

Davies L, Bates JW, Bell JNB, James PW, Purvis WO (2007) Diversity and sensitivity of epiphytes to oxides of nitrogen in London. Environ Pollut 146(2):299-310

DEFRA (Department Environment, Forestry, Agriculture) (2015) National Atmospheric Emissions Inventory (NAEI) http://naei.defra.gov.uk/data/. Accesssed 5 Apr 2016

Dittrich S, Hauck M, Schweigatz D, Dörfler I, Hühne R, Bade C, Jacob M, Leuschner C (2013) Separating forest continuity from tree age effects on plant diversity in the ground and epiphyte vegetation of a Central European mountain spruce forest. Flora Morphol Distrib Funct Ecol Plants 208(4):238-246

Egea JM, Torrente P (1994) El género de hongos liquenizados lecanactis (Ascomcotina). Bibl Lichenol 54:1-205

Ellis C (2013) Lichen epiphyte diversity: a species, community and trait-based review. Perspect Plant Ecol $14: 131-152$

Ellis C, Coppins BJ (2010) Partitioning the role of climate, pollution and old-growth woodland in the composition and richness of lichens epiphytes in Scotland. Lichenologist 42(5):601-614

European Comission (2012) Natura 2000 network http://ec.europa.eu/environment/nature/natura2000/ index_en.htm. Accesssed 5 Apr 2016

Fritz O, Gustafsson L, Larsson K (2008) Does forest continuity matter in conservation? -A study of epiphytic lichens and bryophytes in beech forests of southern Sweden. Biol Conserv 141:655-668

Giordani P, Brunialti G, Bacaro G, Nascimbene J (2012) Functional traits of epiphytic lichens as potential indicators of environmental conditions in forest ecosystems. Ecol Indic 18:413-420

Harding PT, Rose F (1986) Pasture-woodlands in lowland Britain. ITE (NERC), Huntingdon

Hauck M, Jürgens SR, Brinkmann M, Herminghaus S (2008) Surface hydrophobicity causes $\mathrm{SO}_{2}$ tolerance in lichens. Ann Bot Lond 101:531-539

Hawksworth DL (1974) Lichens as indicators of environmental change. Environ Change 2:381-386

Hedenås H, Blomberg P, Ericson L (2007) Significance of old aspen (Populus tremula) trees for the occurrence of lichen photobionts. Biol Conserv 135:380-387

Johansson P, Ehrlén J (2003) Influence of habitat quantity, quality and isolation on the distribution and abundance of two epiphytic lichens. J Ecol 91(2):213-221

Johansson V, Snäll T, Ranius T (2013) Estimates of connectivity reveal non-equilibrium epiphyte occurrence patterns almost 180 years after habitat decline. Oecologia 172(2):607-615

Kaplan JO, Kristen M, Krumhardt A, Zimmermann N (2009) The prehistoric and preindustrial deforestation of Europe. Quat Sci Rev 28:3016-3034

Lange OL, Kilian E (1985) Reaktivierung der Photosynthese trockener Flechten durch Wasserdampfaufnahme aus dem Luftraum: artspezifisch unterschiedliches Verhalten. Flora 176:7-23

Lange OL, Ziegler H (1986) Different limiting processes of photosynthesis in lichens. In: Marcelle R, Clijsters H, Van Poucke M (eds) Biological Control of Photosynthesis. Martinus Nijhoff Publishers, Dordrecht, pp 147-161

Lange OL, Kilian E, Ziegler H (1986) Water vapor uptake and photosynthesis of lichens: performance differences in species with green and blue-green algae as phycobionts. Oecologia 71:104-110

Larsen RS, Bell JNB, James PW, Chimonides J, Rumsey FJ, Tremper A, Purvis WO (2007) Lichen and bryophyte distribution on oak in London in relation to air pollution and bark acidity. Environ Pollut 146(2):332-340

Leppik E, Jüriado I, Liira J (2011) Changes in stand structure due to the cessation of traditional land use in wooded meadows impoverish epiphytic lichen communities. Lichenologist 43(3):257-274

Lepš J, Šmilauer P (2003) Multivariate analysis of ecological data using CANOCO. Cambridge University Press, Cambridge

Maechler M, Rousseeuw P, Struyf A (2016) Cluster: cluster analysis basics and extensions. R package version $2: 4$

Marini L, Nascimbene J, Nimis PL (2011) Large-scale patterns of epiphytic lichen species richness: photobiont dependent response to climate and forest structure. Sci Total Environ 409(20):4381-4386

McCarthy PM (2003) Catalogue of the lichen family Porinaceae. Bibl Lichenol 87:1-164 
Morgan-Huws DI, Haynes FN (1973) Distribution of some epiphytic lichens around an oil refinery at Fawley, Hampshire. In: Ferry BJ, Baddley MS, Hawksworth DL (eds) Air Pollution and Lichens. The Athlone Press, London, pp 89-108

Motulsky HJ (2014) Common misconceptions about data analysis and statistics. J Pharmacol Exp Ther 172:2126-2132

Newton AC (ed) (2010) Biodiversity in the New Forest. Pisces publications, Newbury

R Core Team (2016) R: A language and environment for statistical computing. R Foundation for Statistical Computing, Vienna, Austria. http://www.R-project.org. Accesssed 5 Apr 2016

Ranius T, Eliasson P, Johansson P (2008) Large-scale occurrence patterns of red-listed lichens and fungi on old oaks are influenced both by current and historical habitat density. Biol Conserv 17(10):2371-2381

Rose F (1976) Lichenological indicators of age and environmental continuity in woodlands. In: Brown DL, Hawksworth DJ, Bailey RH (eds) Lichenology: progress and problems. Academic Press, London, pp 279-307

Rose F (1992) Temperate forest management: its effects on bryophyte and lichen floras and habitats. In: Bates JW, Farmer AM (eds) Bryophytes and lichens in a changing environment. Clarendon Press, Oxford, pp 211-233

Rose F, James PW (1974) Regional studies on the British lichen flora I. The corticolous and lignicolous species of the New Forest, Hampshire. Lichenologist 6:1-72

Sanderson NA (2007) New Forest inclosure habitats, habitat fragmentation \& landscape history. Hampshire Isle of Wight WildlifeTrust, Botley

Sanderson NA (2010) Lichens. In: Newton AC (ed) Biodiversity in the New Forest. Pisces publications, Newbury, pp 84-111

Scheidegger C, Groner U, Keller C, Stofer S (2002) Biodiversity assessment tools—Lichens. In: Nimis PL, Scheidegger C, Wolseley PA (eds) Monitoring with Lichens- Monitoring Lichens. Kluwer, Dordrecht, pp 359-365

Schöller H (1997) Some aspects concerning the influence of substrate, biotope, and organism-specific factors on decline and threat of lichens in Central Europe, particular Hesse (Germany). Bibl Lichenol 67:267-276

Sparrius LB (2004) A monograph of Enterographa and Sclerophyton. Bibl Lichenol 89:1-141

Tubbs CR (2001) The New Forest. New Forest Ninth Centenary Trust, Lyndhurst

Vera FWM (2000) Grazing ecology and forest history. CABI Publishing, Wallingford

Woods RG, Coppins BJ (2012) A conservation evaluation of British lichens and lichenicolous fungi. British Lichen Society, London 